\title{
Tree and stand level estimations of Abies alba Mill. aboveground biomass
}

\author{
Andrzej M. Jagodziński ${ }^{1,2} \cdot$ Marcin K. Dyderski $^{1} \cdot$ Kamil Gęsikiewicz $^{1}$ • Paweł Horodecki ${ }^{1}$
}

Received: 5 February 2019 / Accepted: 25 April 2019 /Published online: 15 May 2019

(C) The Author(s) 2019

\begin{abstract}
- Key message We provided a complete set of tree- and stand-level models for biomass and carbon content of silver fir Abies alba. This allows for better characterization of forest carbon pools in Central Europe than previously published models. The best predictor of biomass at the stand level is stand volume, and the worst are stand basal area and density. - Context Among European forest-forming tree species with high economic and ecological significance, Abies alba Mill. is the least characterized in terms of biomass production.

- Aims To provide a comprehensive set of tree- and stand-level models for A. alba biomass and carbon stock. We hypothesized that (among tree stand characteristics) volume will be the best predictor of tree stand biomass.

- Methods We studied a chronosequence of 12 A. alba tree stands in southern Poland (8-115 years old). We measured tree stand structures, and we destructively sampled aboveground biomass of 96 sample trees $(0.0-63.9 \mathrm{~cm}$ diameter at breast height). We provided tree-level models, biomass conversion and expansion factors (BCEFs) and biomass models based on forest stand characteristics.

- Results We developed general and site-specific tree-level biomass models. For stand-level models, we found that the best predictor of biomass was stand volume, while the worst were stand basal area and density.

- Conclusion Our models performed better than other published models, allowing for more reliable biomass predictions. Models based on volume are useful in biomass predictions and may be used in large-scale inventories.
\end{abstract}

Keywords Allometric equations $\cdot$ Biomass allocation $\cdot$ Biomass conversion and expansion factors $\cdot$ IPCC guidelines $\cdot$ Silver fir

\section{Introduction}

One of the most important services of forest ecosystems is sequestration of carbon dioxide in tree biomass (IPCC 2013;

Handling Editor: Shuqing Zhao

Contribution of the co-authors conceptualization, methodology, study design, A.M.J.; data collection and analyses, K.G., P.H., M.K.D., A.M.J.; draft preparation and editing, M.K.D., K.G., P.H., A.M.J.; supervision, A.M.J.

Andrzej M. Jagodziński

amj@man.poznan.pl

1 Institute of Dendrology, Polish Academy of Sciences, Parkowa 5, 62-035 Kornik, Poland

2 Faculty of Forestry, Department of Game Management and Forest Protection, Poznań University of Life Sciences, Wojska Polskiego 71c, 60-625 Poznan, Poland
Rieger et al. 2017; Felipe-Lucia et al. 2018). Forest ecosystems are one of the most important pools of carbon, estimated to accumulate $2.4 \pm 0.4 \mathrm{Pg} \mathrm{C}_{\text {year }}{ }^{-1}$ (Pan et al. 2011). For that reason, in the Anthropocene epoch and changing climate, this function of forests has gained special attention of scientists, practitioners, and policymakers (Meier et al. 2012; Seidl et al. 2016; Sohngen and Tian 2016). As carbon content in plant tissues is less variable than biomass per se, most carbon assessments are focused on patterns of biomass variability (Schepashenko et al. 1998; Thurner et al. 2014; Neumann et al. 2016). For that reason, the last 50 years of forest ecology has yielded the development of thousands of allometric models for proper biomass estimation, both at tree (e.g., Baskerville 1972; Zianis et al. 2005; Forrester et al. 2017) and stand levels (e.g., Lehtonen et al. 2004; Teobaldelli et al. 2009; Schepaschenko et al. 2018).

Precise assessment of carbon balance in forest ecosystems is possible due to detailed studies of particular species and site conditions, as biomass accumulation patterns depend on tree 
stand age (e.g., Peichl and Arain 2007; Donnelly et al. 2016; Jagodziński et al. 2018a), climate (e.g., Oleksyn et al. 1999; Schepaschenko et al. 2018), soil fertility (e.g., Rademacher et al. 2009; Lehtonen et al. 2016) or successional stage (e.g., Kuznetsova et al. 2011; Jagodziński et al. 2017). In recent decades, researchers developed very precise tools for biomass assessment for the main forest tree species (Zianis et al. 2005; Teobaldelli et al. 2009; Forrester et al. 2017). Although there are also general models, allowing biomass estimates for tree species which have not been studied, their accuracy is usually lower than species-specific models.

One of the least characterized tree species in terms of biomass production and carbon sequestration is Abies alba Mill. (Forrester et al. 2017). This is a large (up to $60 \mathrm{~m}$ height), longlived (up to 500-600 years old) late-successional coniferous tree species growing naturally in Central Europe and the mountains of southern Europe (Mauri et al. 2016). A. alba occurs from Polish lowlands up to elevations of $2000 \mathrm{~m}$ in the Alps. Its native distribution ranges from the Carpathians in the east to the Pyrenees in the west and from southern Italy in the south to the Polish lowlands in the north. This species is also cultivated in western France and Denmark (Nord-Larsen and Nielsen 2015). A. alba growing stock in Europe in 2010 was estimated to be 694.4 million $\mathrm{m}^{3}$, making it the sixth most important forestry tree species (FAO 2015). Due to high productivity of A. alba stands, as well as non-resinous and light wood, this species is the second most economically important tree in the mountain forests of Europe. Due to its relatively high temperature requirements, this species is predicted to increase its geographical range due to climate change and its potential future range expansion will be more extensive than future range contraction (Dyderski et al. 2018). Thus, the importance of this species is likely to increase, due to predicted retreat of Picea abies (Dyderski et al. 2018; Thurm et al. 2018).

A comprehensive review of the published European treelevel allometric models comprised only six models for A. alba (Zianis et al. 2005; Muukkonen and Mäkipää 2006): including only one for aboveground biomass, one for woody aboveground biomass, two for crown biomass (branches and foliage), one for stumps, and one for dead branches. Moreover, five of them came from the same source (Italy; Gasparini et al. 2006). In a more recent review, Forrester et al. (2017) found only ten models. After a comprehensive literature review, we collected 33 published models (including those generated by Forrester et al. 2017). Except for a dataset of young trees with 399 sample trees (Annighöfer et al. 2016) and crown biomass models of Ledermann and Neumann (2006), previous studies showed either a low number of sample trees (up to 48) or limited range of diameters. Most of these studies come from southern Europe, with the exception of plots from Denmark (Nord-Larsen and Nielsen 2015), outside the native range of A. alba. At the stand level, BCEFs (biomass conversion and expansion factors) were provided for Abies spp. by Teobaldelli et al. (2009) as a function of age and growing stock, as well as estimates of BCEFs for coniferous trees in temperate climate by IPCC (Eggleston et al. 2006). Much more data is available for A. sibirica (e.g., Lakida et al. 1996; Schepashenko et al. 1998). However, due to different climate and soil conditions of its growth, resulting in different biomass allocation (Oleksyn et al. 1999; Schepaschenko et al. 2018), these models are not transferable to temperate forests of Europe.

Our literature review (previous paragraph) revealed that there is a great disproportion between the relatively wide distribution of $A$. alba, its quantitative and cultural importance for forestry, and the amount of biomass data available for the species (33 models). The number of models per area of species distribution, according to Forrester et al. (2017), is one of the lowest among European tree species (6.7 models per percentage of Europe's forest area where that species occurs, according to Köble and Seufert 2001; using our search results22.1). Thus, we aimed to provide a comprehensive set of tree- and stand-level models for A. alba biomass and carbon stock, as well as to assess changes in tree stand biomass and its allocation patterns with increasing age. We hypothesized that among available tree stand characteristics, volume will be the best predictor of tree stand biomass.

\section{Material and methods}

\subsection{Study sites and material}

We established a set of 12 study plots to cover the whole chronosequence of $A$. alba tree stands from 8 to 115 years old (Table 1). Plots were established in southern Poland $\left(15.6736^{\circ} \mathrm{E}-19.6546^{\circ} \mathrm{E} ; 49.5263^{\circ} \mathrm{N}-50.9588^{\circ} \mathrm{N}\right.$; Table 1$)$, at elevations of $303-889 \mathrm{~m}$ a.s.1. $($ mean $=496.5, \mathrm{SE}=$ $52.7 \mathrm{~m}$ a.s.1.). The plots were selected from stands in the Forest Data Bank (Bank Danych o Lasach 2015) with A. alba volume proportion over $70 \%$ and growing on mesic and fertile soils, typical of natural A. alba forests (Mauri et al. 2016). We also ensured that selected tree stands were not thinned or damaged in the previous 5 years. Within each tree stand, we established a rectangular plot, covering at least 100 trees of A. alba. Thus, plot area ranged from 0.239 to 0.680 ha.

\subsection{Methods}

Within all study plots, we measured diameter at breast height (DBH) of every tree and tree heights $(H)$ of at least $20 \%$ of the trees. Due to low height in the youngest tree stand ( 8 years old), we measured diameter at root collar (DRC) and in the 13year-old stand, we measured diameter at $0.5 \mathrm{~m}\left(D_{0.5}\right)$. We used these diameters for modeling, as in the case of young trees they are robust as biomass predictors (Jagodziński et al. $2018 b)$. For each plot, we determined stand density $(N)$, mean 


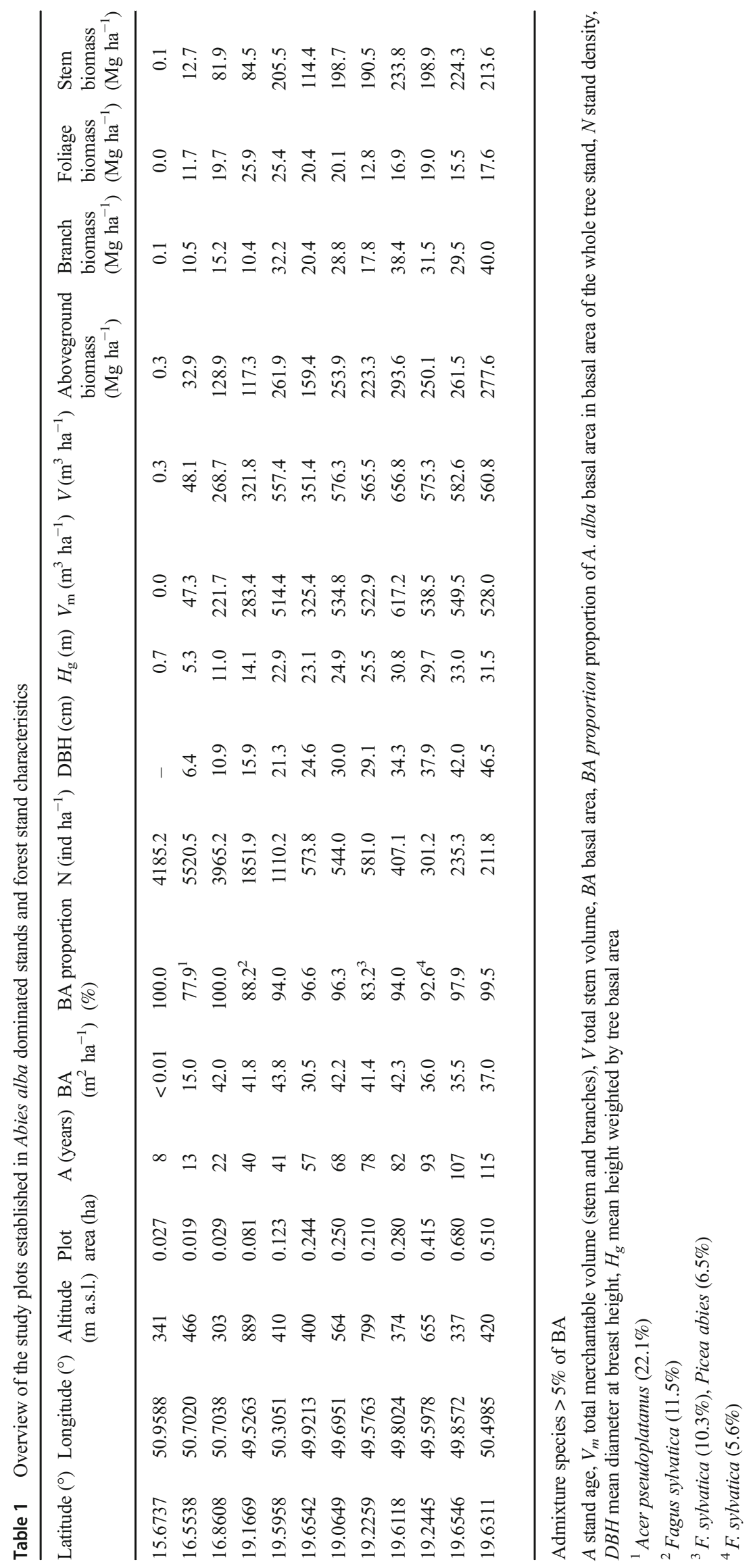


height weighted by tree basal area $\left(H_{\mathrm{g}}\right)$, stand volume $(V)$, and age $(A)$. After dimensional measurements, we divided trees into nine diameter quantiles. Next we selected trees at the borders of each quantile as sample trees (eight sample trees per plot) to ensure good representation of all diameter classes. After the sample trees were cut down, we divided each sample tree into stem, branches, and foliage. We took randomly selected samples from branches with foliage (at least $5 \%$ of the tree crown fresh mass, representing lower, upper and middle parts of the crown) and divided it into foliage and branches in the lab by removing all individual needles from the branches. This allowed us to assess the proportion of each component as a representative of the whole crowns. To obtain tree stem volume, we measured two diameters (perpendicularly) at 1-m-long intervals along the stem. Then, we divided the stem into three sections of equal length and from the middle of each, we cut off a 10-15-cm-thick disc. In the field, we measured two diameters of discs (maximal and perpendicular to maximal) and four height (at the two perpendicular diameters) to calculate disc volume. In the lab, we divided discs into stem wood and stem bark to assess proportion of these components in whole stem biomass. We decided to use this approach as sufficient for proper wood density estimation according to Ochał et al. (2018).

We oven-dried all samples to constant mass $\left(75^{\circ} \mathrm{C}\right)$ and then weighed them with an accuracy of $1 \mathrm{~g}$. We used the proportions of fresh and dry masses of samples and total fresh masses of biomass components (obtained in the field) to calculate total biomass of each tree component. For stems, we calculated dry mass using proportion between discs and stem section volumes and dry masses of the discs. We did not analyze the biomass of dead branches and cones separately, as their proportions strongly vary across study sites and tree stand age. We incorporated them into total aboveground biomass. We analyzed biomass of stem bark, stem wood, branches, foliage, stem (stem wood and stem bark), aboveground woody part of tree (stem and branches), and total aboveground biomass.

We assessed carbon content in main biomass components: stem wood, stem bark, branches, and foliage. For each sample tree, we analyzed three samples of stem wood and bark (from each disc) and one sample of foliage and branches. In total, we analyzed 64 samples per study plot (24 of stem wood and bark and eight of branches and foliage). We determined carbon content with an ECS CHNS-O 4010 Elemental Combustion System (Costech Instruments, Italy/USA) and a CHNS/O Analyzer 2400 Series II (PerkinElmer, USA).

\subsection{Data analysis}

We used R software (R Core Team 2018) for all data analyses. We calculated heights of each tree using measurements of heights and site-specific Naslund's models from the Imfor::ImputeHeights() function (Mehtatalo 2008). Tree level biomass models were compiled for the tree components for each study plot (site-specific models) using formulas from Table 2. Model selection was based on the goodness of fit by using Akaike's Information Criterion (AIC). However, we also evaluated pseudo- $R^{2}$ and RMSE and we visually inspected residual distributions to assess the level of homoscedasticity. We decided to not exclude parameters which are statistically insignificant. For biomass prediction, it is not important whether any single parameter is significant or not, but which model has the highest predicting power. Moreover, lack of statistical significance may be not connected with lack of effects but may be related to small sample size or shape of an allometric curve. Because the relationship between tree dimensions and biomass is non-linear, reduction of parameter $b$ would lead to linearization of the non-linear model and violation of the assumption of non-linearity. Following recommendation of the American Statistical Association (Wasserstein and Lazar 2016), we decided to not focus on significance of the parameters. Moreover, we developed a set of general models, using all sample trees for models based on DBH and using 16 sample trees from 8- and 13-year-old plots, based on DRC and $D_{0.5}$. In each model, we assumed normal distribution of errors, as well as uniform variance of residuals along the predicted variable. To exclude site-specific effects from models, we applied mixed effects models. Plot ID was assigned as a random effect to maintain independence of observations within the dataset. Following Forrester et al. (2017), we tested linearized forms of allometric models (Table 2). For random factors in the models, we provided values of SD of plot-specific random effects. For backward transformation of log-transformed models, we provided correction factors $\left(\mathrm{CF}=\exp \left(\mathrm{SEE}^{2} / 2\right)\right)$, where $\mathrm{SEE}$ was standard error of the estimate based on natural logarithms (Sprugel 1983). Mixed effects models were developed using the lmer and lmerTest packages (Bates et al. 2015; Kuznetsova et al., 2017). Model selection was based on the goodness of fit using Akaike's Information Criterion (AIC). For each mixed effects model, we also calculated two coefficients of determination, allowing us to assess the proportion of variance explained by fixed and both random and fixed effects. Marginal coefficients of determination $\left(R_{\mathrm{m}}^{2}\right)$ express the amount of variance explained by fixed effects only and conditional coefficients of determination $\left(R_{\mathrm{c}}^{2}\right)$ express the amount of variance explained by both random and fixed effects. These coefficients were calculated using the MuMIn::r.squaredGLMM() function (Bartoń, 2017).

For the model validation, we selected one of the best fitting models for each study and biomass component among treelevel models published for A. alba. After verification, we used 16 models for comparison with our general models. We applied them to our sample trees to compare differences between observed and predicted biomasses. To avoid extrapolation biases, we decided to apply these functions only to trees within 
Table 2 Formulas of regression models used in the study

\begin{tabular}{|c|c|c|c|c|}
\hline Type of models & Formulas & Dependent variables $(Y)$ & Independent variables & References \\
\hline $\begin{array}{l}\text { Site-specific tree-level } \\
\text { models }\end{array}$ & $\begin{array}{l}\text { (1) } Y=a \times D^{\mathrm{b}} \\
\text { (2) } Y=a+b \times D^{2} \\
\text { (3) } Y=a+b \times \log (D) \\
\text { (4) } Y=a+(b / D) \\
\text { (5) } Y=a \times\left(D^{2} H\right)^{\mathrm{b}} \\
\text { (6) } Y=a \times D^{\mathrm{b}} \times H^{\mathrm{c}} \\
\text { (7) } Y=a+b \times \log \left(D^{2} H\right) \\
\text { (8) } Y=a+b \times D^{2}+c \times H \\
\text { (9) } Y=a+b \times\left(D^{2} H\right) \\
\text { (10) } Y=a+b \times D^{2}+c \times H^{2}\end{array}$ & $\begin{array}{l}\text { Biomass (dry weight) of } \\
\text { the tree component }(\mathrm{kg})\end{array}$ & $\begin{array}{l}\mathrm{D} \text { - diameter }(\mathrm{cm}) \\
\mathrm{H} \text { - height }(\mathrm{m}) \\
\mathrm{D}^{2} \mathrm{H} \text { - pseudovolume }\left(\mathrm{m}^{3}\right)\end{array}$ & (Jagodziński et al., 2018a, b) \\
\hline $\begin{array}{l}\text { General tree-level } \\
\text { models }\end{array}$ & $\begin{array}{l}\text { (11) } \log (W)=a+b \times \log (D)+u_{j} \\
\text { (12) } \log (W)=a+b \times \log \left(D^{2} H\right)+u_{j} \\
\text { (13) } \log (W)=a+b \times \log (D) \\
\quad+c \times \log (H)+u_{j}\end{array}$ & $\begin{array}{l}\text { Biomass (dry weight) of } \\
\text { the tree component }(\mathrm{kg})\end{array}$ & $\begin{array}{l}\mathrm{D}-\text { diameter }(\mathrm{cm}), \\
\mathrm{H}-\text { height }(\mathrm{m}), \\
\mathrm{D}^{2} \mathrm{H}-\text { pseudovolume }\left(\mathrm{m}^{3}\right), \\
u_{j} \text {-random intercept for } \\
\quad \text { plot } j .\end{array}$ & (Forrester et al. 2017) \\
\hline Stand-level models & $\begin{array}{l}\text { (14) } Y=a \times z^{\mathrm{b}} \\
\text { (15) } Y=a+b \times e^{-\mathrm{z} \times \mathrm{c}} \\
\text { (16) } Y=a+b / z \\
\text { (17) } Y=a+b / z^{\mathrm{c}}\end{array}$ & $\begin{array}{l}\text { Biomass }\left(\mathrm{Mg} \mathrm{ha}^{-1}\right) \\
\text { BCEF }\left(\mathrm{Mg} \mathrm{m}^{-3}\right)\end{array}$ & $\begin{array}{l}z \text { - tree stand characteristics } \\
\text { (stand density, height, } \\
\text { volume or age) }\end{array}$ & $\begin{array}{l}\text { (Teobaldelli et al. 2009; } \\
\text { Wojtan et al. 2011; } \\
\text { Jagodziński et al. 2018b) }\end{array}$ \\
\hline
\end{tabular}

a, b, c-model parameters, e- base of the natural logarithm

the dimension range of a particular function or trees which differed from its minimal or maximal values by not more than $20 \%$. We assumed $20 \%$ as a trade-off between comparability and extrapolation bias following our earlier studies (Jagodziński et al. 2018a,b). In the case of models provided by Montero et al. (2005) (three separate models for three branch diameter classes), we compared the sum of masses for each class with branch biomass from our models, as we did not divide branches into categories. According to data provided by the mentioned authors, we assumed that branches with diameter $>7 \mathrm{~cm}$ were not present for trees up to $20 \mathrm{~cm} \mathrm{DBH}$.

For stand-level biomass analyses, we calculated biomass conversion and expansion factors (BCEFs) as BCEF $=W / V$, where $\mathrm{W}$ - dry mass of the considered biomass component $\left(\mathrm{Mg} \mathrm{ha}^{-1}\right)$ and $V$-total stem volume of trees $\left(\mathrm{m}^{3} \mathrm{ha}^{-1}\right)$. We prepared stand-level estimators for four of the most important biomass components - total aboveground biomass, branches, foliage, and stem. To assess the relationships between tree stand characteristics and BCEFs, we used following model types (Teobaldelli et al. 2009; Wojtan et al. 2011; Jagodziński et al. 2018b; Table 2). In each model, we assumed normal distribution of errors, as well as uniform variance of residuals along the predicted variable. We also used these models (Eqs. 14-17 in Table 2) to predict relationships between tree stand characteristics and biomass. We used AIC as the main criterion in selection of the best model; however, we also evaluated pseudo- $R^{2}$ and RMSE and we visually inspected residual distributions to assess the level of homoscedasticity. We also compared quality among models using AIC of each model and the background of $\mathrm{AIC}_{0}-\mathrm{AIC}$ of the null model (intercept only). Due to intercorrelations between tree stand characteristics (connected with age dependence) and related variance inflation, we decided not to provide multiple regression models for tree stand biomass and BCEFs. Moreover, small sample size (12 plots) would decrease reliability of multiple regression analysis. We compared our stand level total aboveground biomass estimations using both BCEFs and biomass models (based on $V$ and on $H_{\mathrm{g}}$ ) with those provided by Teobaldelli et al. (2009) and by IPCC. For biomass calculation using BEF (biomass expansion factors; $\mathrm{m}^{3} \mathrm{~m}^{-3}$ ), which returns biomass after multiplying by wood density, we applied $0.353 \mathrm{Mg} \mathrm{m}^{-3}$ (Chave et al. 2009). Due to lack of merchantable volume, we excluded the youngest plots from stand-level BCEF analyses. We compared methods of stand-level biomass estimation using mean error, i.e., mean difference between observed and predicted biomass (ME).

\section{Results}

\subsection{Tree-level models}

Site-specific allometric models developed for study sites explained from 95.3 to $99.8 \%$ (average $98.2 \pm 0.4 \%$ ) of variation in total aboveground biomass, depending on diameter type. For branches, foliage, and stem biomass, coefficients of determination varied from 0.850 to 0.993 , from 0.884 to 0.997 , and from 0.961 to 0.997 , respectively. Fixed effects of general allometric models explained from 90.5 to $99.6 \%$ of variation in biomass (Table 3). Plot-specific (random) effects explained from 0.0 to $5.9 \%$ of variance. There were no plot-specific effects for five models based on $D_{0.5}$ and four based on DRC. Stem and total aboveground biomass models had better fits than those for branches and foliage. Similarly, site-specific 


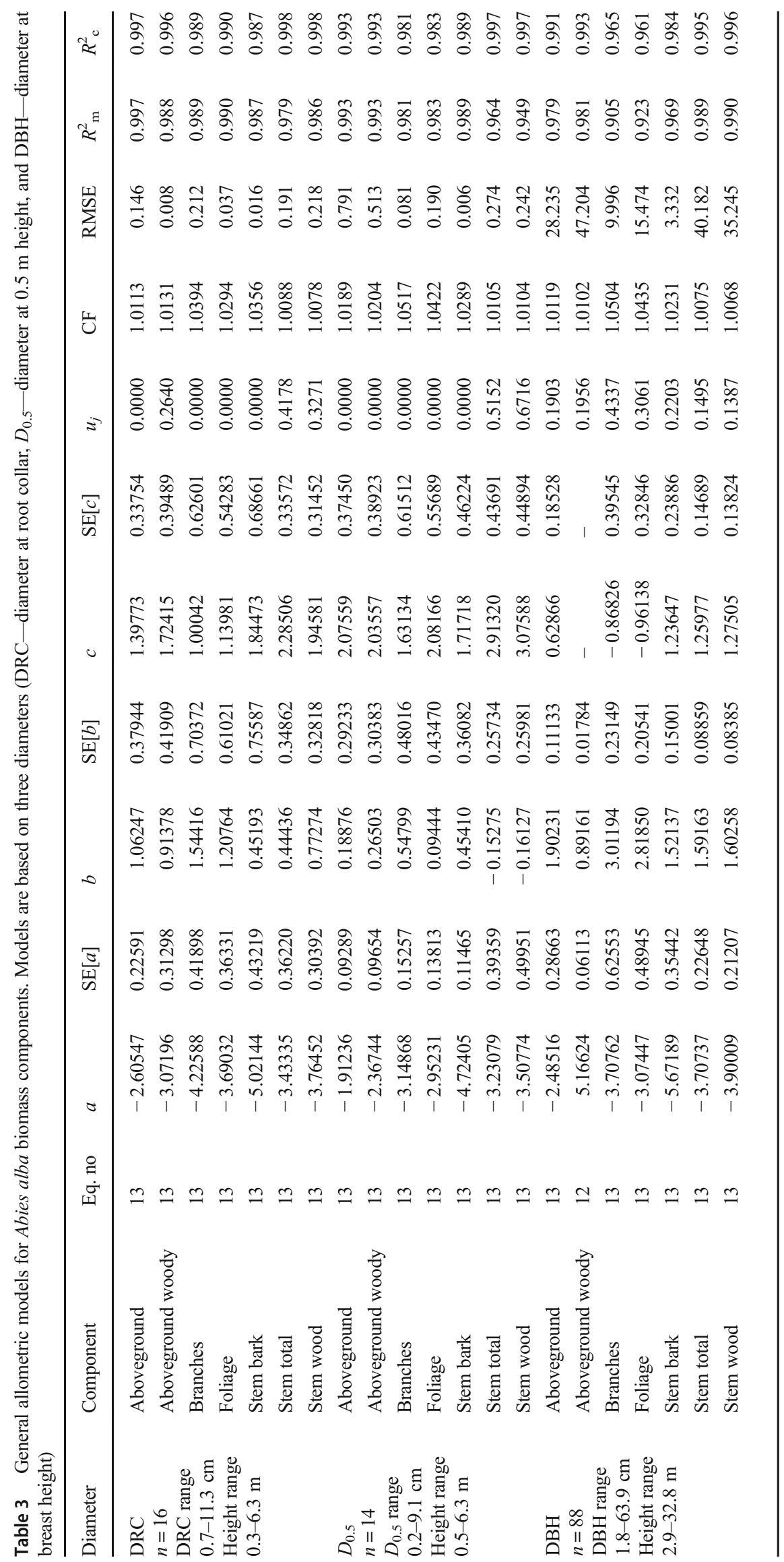


effects in models based on DBH were highest in models of branches and foliage.

\subsection{Comparison of models accuracy of general and published tree-level models}

Analysis of comparison with original data revealed that models from Denmark (Nord-Larsen and Nielsen 2015) and Switzerland (Burger 1951) underestimated biomass of A. alba (Fig. 1). However, model of ST from Denmark performed similarly to our general models. Models from Italy (Gasparini et al. 2006; Tabacchi et al. 2011) had small underestimations of aboveground woody biomass and stem biomass but well-fit estimates of total aboveground biomass. Models from Spain (Montero et al. 2005; Ruiz-Peinado et al. 2011) had overestimations of total aboveground, stem, and branch biomass. For small trees, our general model provided estimates similar to the model provided by Annighöfer et al. (2016). Our general models provided reliable predictions in low and medium ranges of biomass, while they tended to underestimate biomass of the two largest sample trees.

\subsection{Models for stand level biomass and BCEFs}

The biomass of A. alba was strongly positively correlated with tree stand age, volume, mean diameter, height, and basal area (Fig. 2; Table 4). We found the highest correlations for total aboveground and stem biomass and the lowest for foliage. The weakest predictor among all analyzed biomass components was stand density $(N)$. In case of BCEFs, we found that the values for the youngest tree stand were more or less constant and weakly negatively correlated with tree stand age, volume, mean diameter, height, and basal area (Fig. 3; Table 5). The most constant pattern was observed in BCEFs for branches.

\subsection{Comparison of stand-level biomass models}

Comparing stand-level biomass estimation methods, we found the best accuracy of our volume-based (ME = $0.5 \mathrm{Mg} \mathrm{ha}^{-1}$ ) and height-based ( $\mathrm{ME}=-0.6 \mathrm{Mg} \mathrm{ha}^{-1}$ ) models, as well as using the BCEF-based approach $(\mathrm{ME}=$ $1.1 \mathrm{Mg} \mathrm{ha}^{-1}$ ). Age-based and volume-based BEF models of Teobaldelli et al. (2009) had lower quality, with ME of 8.6 and

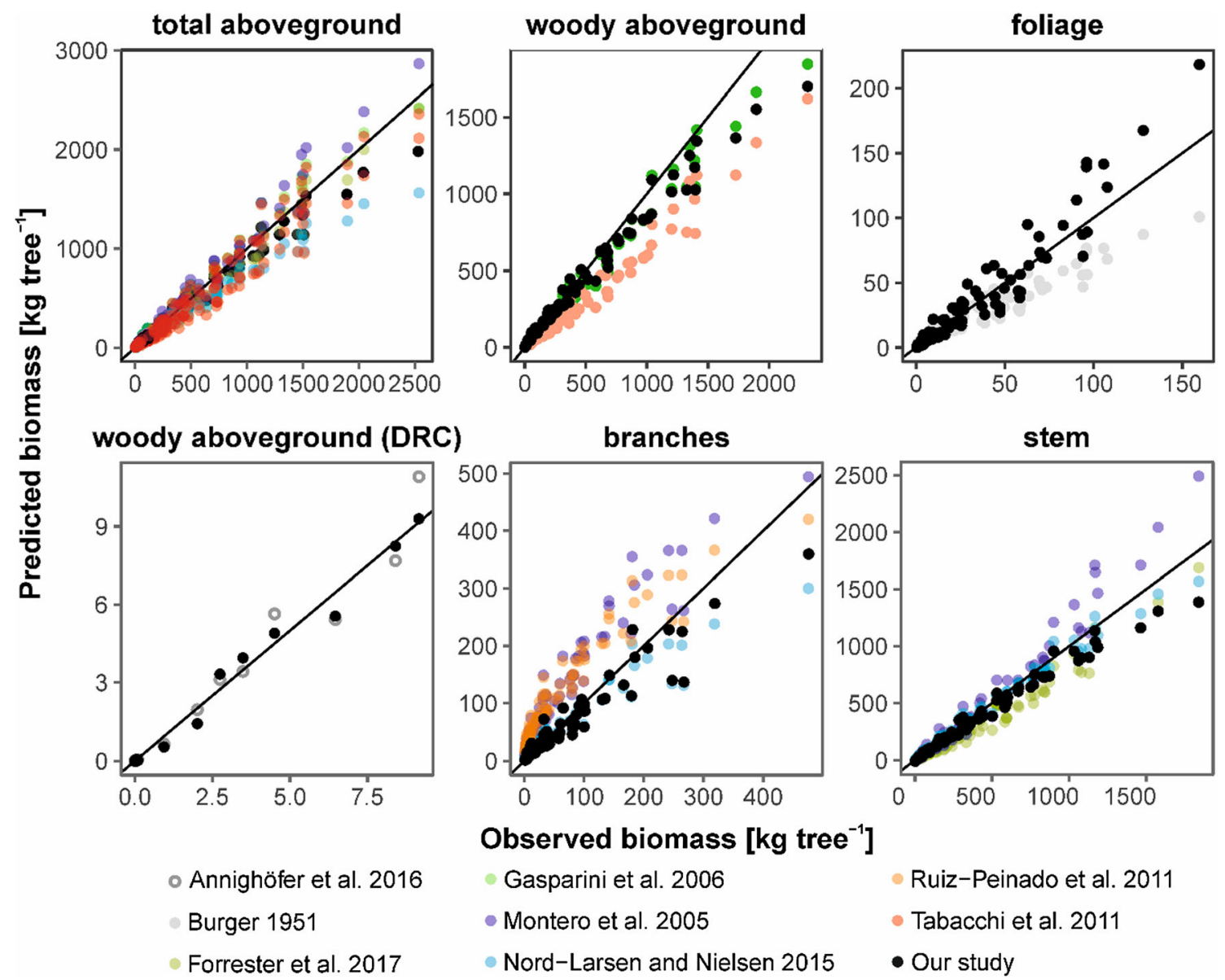

Fig. 1 Biomasses calculated by our general models (black dots) and published models, compared with measurements of biomass. Line indicates 1:1 proportion. Note that we showed only trees fitted to the dimension range of functions used or which differed from their minimal or maximal values by not more than in $20 \%$ 


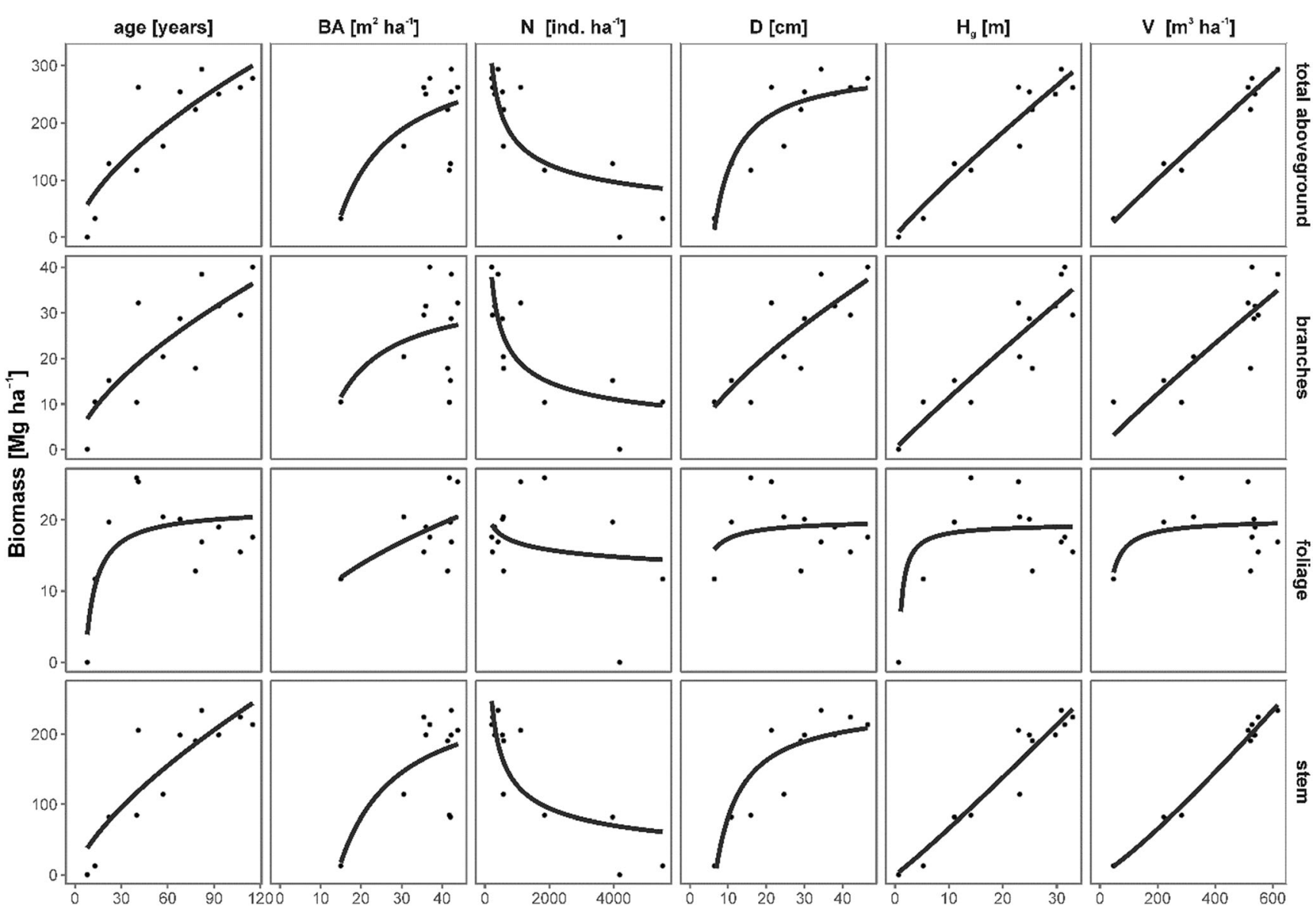

Fig. 2 Non-linear models describing relationships between tree stand characteristics and tree stand biomass components: total aboveground, branches, foliage, and stem. Parameters of non-linear regression models are presented in Table 4

33.1 $\mathrm{Mg} \mathrm{ha}^{-1}$, respectively. The approach recommended by IPCC provided strongly overestimated biomass, with ME of $-86.8 \mathrm{Mg} \mathrm{ha}^{-1}$. This method deviated the most for stands with the largest observed biomass (Fig. 4).

\subsection{Carbon content}

Mean carbon content in aboveground biomass ranged from $49.4 \%$ in the 8 -year-old tree stand to $50.7 \%$ in the 40 -yearold tree stand, with an average of $50.0 \pm 0.1 \%$ (Table 6). Mean carbon content in stem wood was of $49.6 \pm 0.1 \%$, for stem bark of $49.8 \pm 0.3 \%$, for branches of $50.6 \pm 0.2 \%$, and for foliage of $51.9 \pm 0.2 \%$.

\section{Discussion}

\subsection{Accuracy of the tree-level models}

The tree-level models of A. alba in S Poland developed in our study revealed good accuracy for most of the biomass components studied. Generally, models from Spain (Montero et al. 2005; Ruiz-Peinado et al. 2011) and Italy (Gasparini et al.
2006; Tabacchi et al. 2011) overestimated biomass of A. alba trees from our study. In the case of models provided by Montero et al. (2005), overestimation may result from dividing branch biomass into three diameter categories, described using separate models. This separation would not allow additivity of models, leading to overestimation of the branch biomass. One of these categories are merchantable branches (i.e., with diameter $>7 \mathrm{~cm}$ ), which in our study were present only in trees older than 80 years. Moreover, models from southern Europe describe different growth conditions, mainly from mountains and highlands, which also affect biomass allocation to branches (Jagodziński and Oleksyn 2009a). In contrast, models from Denmark (Nord-Larsen and Nielsen 2015) underestimated biomass of A. alba trees. These observations are consistent with the geographic pattern of biomass allocation and BCEF variability, revealed by Schepaschenko et al. (2018).

\subsection{Accuracy of stand-level biomass models}

We found lower deviations between observed and predicted stand level biomass in models provided by our study than in those provided by Teobaldelli et al. (2009). This of course was connected with usage of our dataset as a reference. However, 
Table 4 Non-linear models describing relationships between forest stand characteristics (predictors) and tree stand biomass $\left(\mathrm{Mg}^{-1}\right)$

\begin{tabular}{|c|c|c|c|c|c|c|c|c|c|c|}
\hline Component & Predictor & Equation & $a$ & SE & $b$ & SE & RMSE & $R^{2}$ & AIC & $\mathrm{AIC}_{0}$ \\
\hline \multirow[t]{6}{*}{ Aboveground } & Age & 14 & 15.5976 & 10.4750 & 0.6230 & 0.1538 & 9.770 & 0.773 & 131.541 & \multirow[t]{6}{*}{147.325} \\
\hline & BA & 16 & 338.4602 & 51.0512 & -4509.9619 & 1602.4894 & 12.021 & 0.658 & 126.535 & \\
\hline & $\mathrm{N}$ & 14 & 2448.9150 & 1579.5938 & -0.3895 & 0.1055 & 8.350 & 0.695 & 135.095 & \\
\hline & $\mathrm{D}$ & 16 & 299.9651 & 20.2692 & -1831.4091 & 314.6267 & 4.083 & 0.865 & 116.305 & \\
\hline & $H_{\mathrm{g}}$ & 14 & 12.3859 & 6.4909 & 0.9005 & 0.1588 & 4.726 & 0.916 & 119.557 & \\
\hline & $V$ & 14 & 0.6978 & 0.4328 & 0.9397 & 0.0995 & 6.597 & 0.977 & 97.075 & \\
\hline \multirow[t]{6}{*}{ Branches } & Age & 14 & 1.8046 & 1.5111 & 0.6331 & 0.1916 & 0.532 & 0.678 & 85.878 & \multirow[t]{6}{*}{97.469} \\
\hline & BA & 16 & 35.6780 & 8.0444 & -362.9002 & 252.5116 & 3.615 & 0.459 & 85.882 & \\
\hline & $\mathrm{N}$ & 14 & 353.6486 & 249.9720 & -0.4176 & 0.1163 & 0.465 & 0.672 & 86.097 & \\
\hline & $\mathrm{D}$ & 14 & 2.5502 & 1.7724 & 0.6983 & 0.1989 & 2.812 & 0.784 & 75.800 & \\
\hline & $H_{\mathrm{g}}$ & 14 & 1.2832 & 1.1028 & 0.9472 & 0.2600 & 0.374 & 0.806 & 79.783 & \\
\hline & $V$ & 14 & 0.0876 & 0.1719 & 0.9321 & 0.3148 & 0.439 & 0.783 & 75.851 & \\
\hline \multirow[t]{6}{*}{ Foliage } & Age & 16 & 21.6134 & 1.9509 & -142.0926 & 41.9580 & 0.000 & 0.534 & 76.089 & \multirow[t]{6}{*}{83.257} \\
\hline & BA & 14 & 3.0297 & 3.3855 & 0.5050 & 0.3065 & 3.758 & 0.728 & 65.275 & \\
\hline & $\mathrm{N}$ & 14 & 31.4709 & 23.2029 & -0.0908 & 0.1109 & 0.047 & 0.075 & 84.317 & \\
\hline & $\mathrm{D}$ & 16 & 20.0025 & 2.3108 & -26.5623 & 35.8690 & 5.006 & 0.635 & 68.532 & \\
\hline & $H_{\mathrm{g}}$ & 16 & 19.4517 & 1.3691 & -13.5397 & 3.2128 & 0.000 & 0.640 & 73.005 & \\
\hline & $V$ & 16 & 20.0868 & 1.5910 & -354.2706 & 232.9451 & 3.980 & 0.692 & 66.667 & \\
\hline \multirow[t]{6}{*}{ Stem } & Age & 14 & 8.8797 & 6.6859 & 0.6985 & 0.1714 & 9.334 & 0.786 & 126.840 & \multirow[t]{6}{*}{143.324} \\
\hline & BA & 16 & 273.1988 & 46.3089 & -3842.5472 & 1453.6294 & 5.493 & 0.607 & 124.390 & \\
\hline & $\mathrm{N}$ & 14 & 2450.7612 & 1709.8093 & -0.4286 & 0.1151 & 8.825 & 0.712 & 130.398 & \\
\hline & $\mathrm{D}$ & 16 & 243.2335 & 17.8532 & -1615.2956 & 277.1247 & 3.093 & 0.854 & 113.513 & \\
\hline & $H_{\mathrm{g}}$ & 14 & 5.6214 & 3.5196 & 1.0691 & 0.1887 & 4.331 & 0.920 & 115.081 & \\
\hline & $V$ & 14 & 0.1367 & 0.0742 & 1.1638 & 0.0868 & 3.711 & 0.989 & 85.550 & \\
\hline
\end{tabular}

Age stand age (years), $B A$ basal area $\left(\mathrm{m}^{2} \mathrm{ha}^{-1}\right), D$ mean diameter $(\mathrm{cm}), H_{g}$ mean height weighted by tree basal area $(\mathrm{m}), N$ stand density (ind ha $\left.{ }^{-1}\right), V$ total stem volume $\left(\mathrm{m}^{3} \mathrm{ha}^{-1}\right)$

Teobaldelli et al. (2009) provided models for Abies spp., without using data for A. alba separately. For that reason, our species-specific models were more reliable, as they contained two species-specific components of variability: wood density and biomass allocation pattern. The former was also included in application of models provided by Teobaldelli et al. (2009); thus, the ME of such models was relatively low. Lack of this information in BCEFs provided by IPCC guidelines (Eggleston et al. 2006) increased their uncertainty. Overestimation caused by usage of coefficients provided by IPCC guidelines was especially high in the tree stands with the highest biomass. For that reason, usage of these models may lead to overestimation of forest biomass carbon pools (Jagodziński et al. 2018a), especially in countries where other methods of biomass assessment are not well developed.

\subsection{Influence of tree stand characteristics on biomass estimation}

Analyses of biomass changes with increases of tree stand characteristics revealed fast biomass increments of foliage in the youngest tree stands, stabilizing after 20 years. Fast increase of foliage biomass in the early years of life followed by stabilization may result from specificity of $A$. alba crown architecture - this species has long and dense crowns (Spathelf 2003; Dobrowolska et al. 2017). This may also result from a quick decrease of leaf mass as a share of total biomass in the early years of life (Mikšys et al. 2007; Poorter et al. 2012; Uri et al. 2012). In contrast, increments of total aboveground biomass and stem biomass were more or less linear. Patterns of biomass accumulation through stand maturation were also reflected in values of BCEFs - the highest BCEF values were noted in the youngest tree stands and then BCEFs stabilized at more or less constant values, similar to other tree species (Lehtonen et al. 2004; Teobaldelli et al. 2009; Jagodziński et al. 2018a).

Biomass was most highly correlated with variables describing tree stand dimensions, i.e., volume, diameter, and height. However, it was weakly correlated with basal area. This may be connected with the growth strategy of $A$. alba, forming tree stands which are multi-storied or selection structure of stands (Dobrowolska et al. 2017). This results in similar basal area of stands with different age and stand dimensions. For the same reasons, stand density was the worst predictor of biomass. 


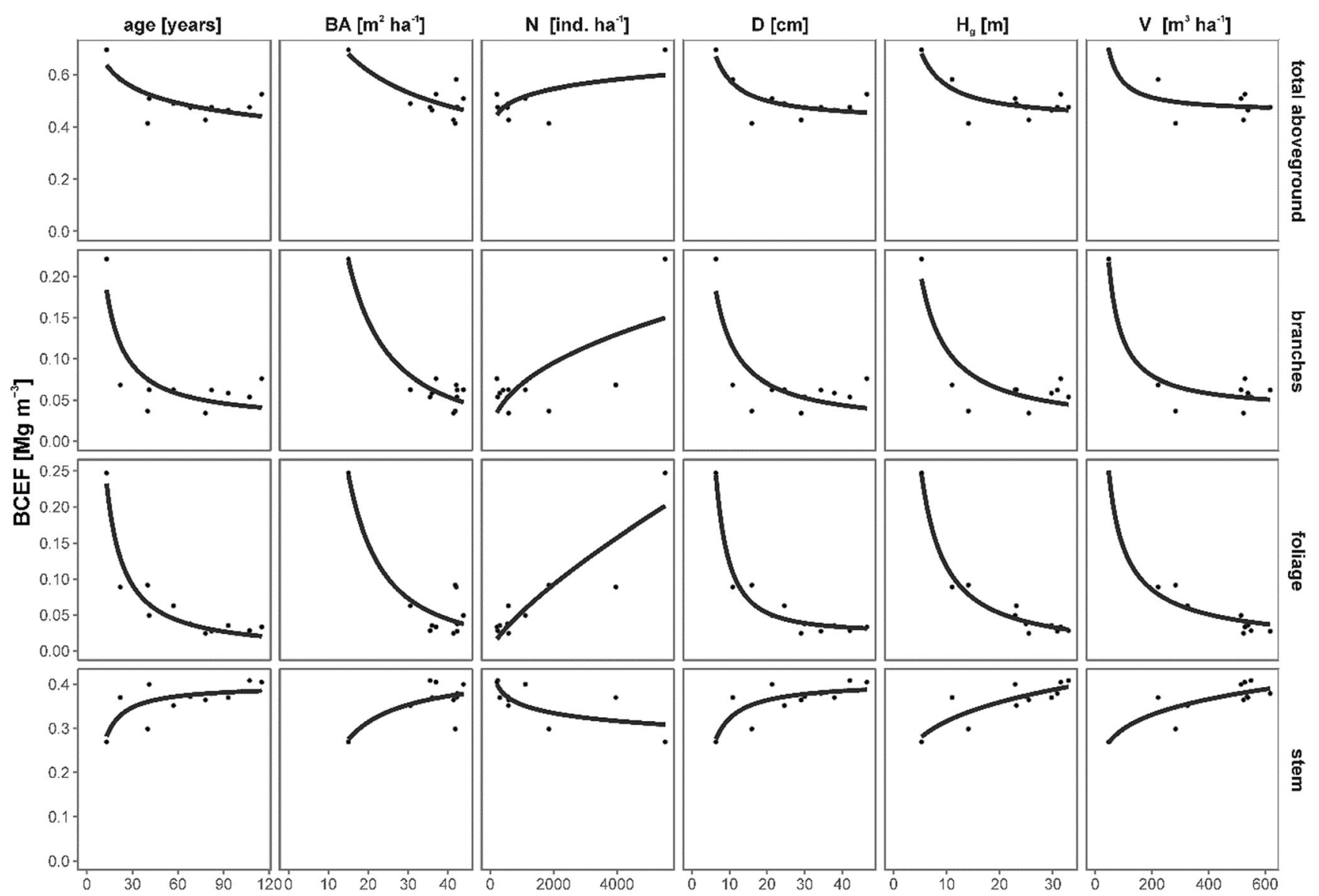

Fig. 3 Non-linear models describing relationships between tree stand characteristics and BCEFs for total aboveground, branches, foliage, and stem biomass. Parameters of non-linear regression models are presented in Table 5

Table 5 Non-linear models describing relationships between forest stand characteristics (predictors) and biomass conversion and expansion factors (BCEFs) $\left(\mathrm{Mg} \mathrm{m}^{-3}\right)$

\begin{tabular}{|c|c|c|c|c|c|c|c|c|c|c|c|c|}
\hline Component & Predictor & Equation & $a$ & SE & $b$ & SE & $c$ & $\mathrm{SE}$ & RMSE & $R^{2}$ & AIC & $\mathrm{AIC}_{0}$ \\
\hline \multirow[t]{6}{*}{ Aboveground } & Age & 16 & 0.42711 & 0.02002 & 3.23549 & 0.65357 & - & - & $<0.0001$ & 0.731 & -34.350 & -21.890 \\
\hline & $\mathrm{BA}$ & 16 & 0.35814 & 0.03994 & 4.91087 & 1.25372 & - & - & $<0.0001$ & 0.630 & -30.836 & \\
\hline & $\mathrm{N}$ & 14 & 0.27545 & 0.06616 & 0.09000 & 0.03464 & - & - & 0.0006 & 0.398 & -25.479 & \\
\hline & $\mathrm{D}$ & 16 & 0.42125 & 0.02382 & 1.58348 & 0.36978 & - & - & $<0.0001$ & 0.671 & -32.112 & \\
\hline & $H_{\mathrm{g}}$ & 16 & 0.42295 & 0.02304 & 1.36205 & 0.31094 & - & - & $<0.0001$ & 0.681 & -32.449 & \\
\hline & $V^{\circ}$ & 16 & 0.45594 & 0.01700 & 11.44751 & 2.48881 & - & - & $<0.0001$ & 0.702 & -33.191 & \\
\hline \multirow[t]{6}{*}{ Branches } & Age & 16 & 0.02281 & 0.01345 & 2.09071 & 0.43905 & - & - & $<0.0001$ & 0.716 & -43.103 & -31.261 \\
\hline & $\mathrm{BA}$ & 14 & 10.54166 & 3.64572 & -1.42971 & 0.11097 & - & - & 0.0015 & 0.928 & -58.246 & \\
\hline & $\mathrm{N}$ & 14 & 0.00314 & 0.00378 & 0.44857 & 0.15488 & - & - & 0.0089 & 0.426 & -35.370 & \\
\hline & $\mathrm{D}$ & 16 & 0.01756 & 0.01501 & 1.05158 & 0.23307 & - & - & $<0.0001$ & 0.693 & -42.267 & \\
\hline & $H_{\mathrm{g}}$ & 16 & 0.01577 & 0.01241 & 0.95407 & 0.16746 & - & - & $<0.0001$ & 0.783 & -46.063 & \\
\hline & $V^{\circ}$ & 16 & 0.03667 & 0.00579 & 8.55722 & 0.84732 & - & - & $<0.0001$ & 0.919 & -56.896 & \\
\hline \multirow[t]{6}{*}{ Foliage } & Age & 14 & 4.04670 & 1.44364 & -1.11395 & 0.12012 & - & - & 0.0070 & 0.919 & -51.740 & -26.114 \\
\hline & $\mathrm{BA}$ & 14 & 27.78346 & 19.40171 & -1.74710 & 0.23352 & - & - & 0.0039 & 0.835 & -43.948 & \\
\hline & $\mathrm{N}$ & 14 & 0.00027 & 0.00034 & 0.76792 & 0.15236 & - & - & 0.0115 & 0.803 & -42.004 & \\
\hline & $\mathrm{D}$ & 17 & 0.02525 & 0.01045 & 6.27813 & 4.30854 & 1.81029 & 0.37889 & $<0.0001$ & 0.960 & -57.554 & \\
\hline & $H_{\mathrm{g}}$ & 14 & 1.66513 & 0.21970 & -1.15334 & 0.06266 & - & - & 0.0004 & 0.975 & -64.697 & \\
\hline & $V^{\circ}$ & 14 & 4.46600 & 0.91985 & -0.74732 & 0.04530 & - & - & 0.0038 & 0.965 & -60.987 & \\
\hline \multirow[t]{6}{*}{ Stem } & Age & 16 & 0.39774 & 0.01469 & -1.51562 & 0.47955 & - & - & $<0.0001$ & 0.526 & -41.162 & -34.949 \\
\hline & $\mathrm{BA}$ & 16 & 0.43163 & 0.02630 & -2.35413 & 0.82543 & - & - & $<0.0001$ & 0.475 & -40.031 & \\
\hline & $\mathrm{N}$ & 14 & 0.61201 & 0.10709 & -0.07956 & 0.02674 & - & - & $<0.0001$ & 0.513 & -40.859 & \\
\hline & $\mathrm{D}$ & 16 & 0.40500 & 0.01445 & -0.82925 & 0.22430 & - & - & $<0.0001$ & 0.603 & -43.110 & \\
\hline & $H_{\mathrm{g}}$ & 14 & 0.20618 & 0.03018 & 0.18514 & 0.04654 & - & - & $<0.0001$ & 0.673 & -45.231 & \\
\hline & $V^{\circ}$ & 14 & 0.15208 & 0.03364 & 0.14652 & 0.03664 & - & - & $<0.0001$ & 0.687 & -45.716 & \\
\hline
\end{tabular}

Age stand age (years), $B A$ basal area $\left(\mathrm{m}^{2} \mathrm{ha}^{-1}\right), D$ mean diameter $(\mathrm{cm}), H_{g}$ mean height weighted by tree basal area (m), $N$ stand density (ind ha $\left.{ }^{-1}\right), V$ total stem volume $\left(\mathrm{m}^{3} \mathrm{ha}^{-1}\right)$ 


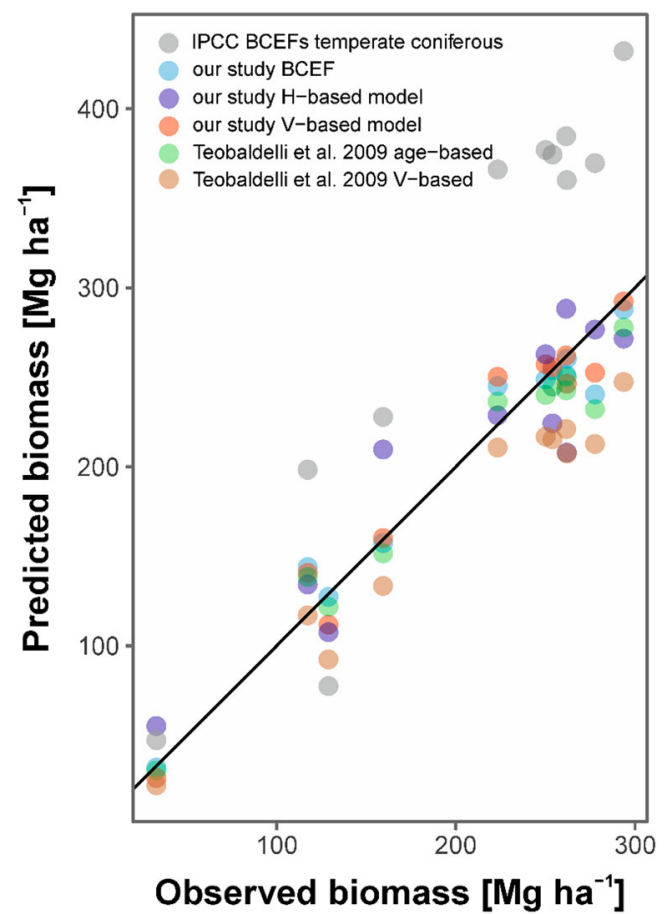

Fig. 4 Comparison of differences between aboveground biomasses calculated by models developed in this study, published models of BCEFs (Teobaldelli et al. 2009) and BCEFs recommended by IPCC guidelines (Eggleston et al. 2006), with observed biomasses (calculated using plot-specific tree-level models). Line indicates 1:1 proportion

Biomass was lowest in stands with the highest density, while BCEFs were highest in those stands. During tree stand development, initial density decreases while trees are growing, due to management thinning and self-thinning of the stand. Stand density is a strong predictor of tree stand productivity and biomass allocation in Pinus sylvestris (Jagodziński and Oleksyn 2009a,b). Our study confirmed this pattern for $A$. alba. Also, Castedo-Dorado et al. (2012) found that stand density was the weakest predictor of tree stand biomass of six tree species, including three conifers: Pinus pinaster, $P$. radiata, and $P$. sylvestris. In the case of $A$. alba, the strong relationship between stand density and productivity may be connected with more dense canopies of A. alba stands in contrast to sparse tree stands of $L$. decidua and Mediterranean stands of Pinus spp.

\subsection{Carbon content}

Mean carbon content in aboveground biomass from our study $(50.00 \pm 0.09 \%)$ did not differ from the value 0.5 , usually assumed as carbon content in plant tissues in most European countries (e.g., Neumann et al. 2016), as well as in other parts of the world (e.g., Lamlom and Savidge 2003). Our results are also in line with IPCC guidelines (Eggleston et al. 2006), providing a mean value of $51 \%$, with a wide range of 47 $55 \%$. However, it differed from the value provided by Montero et al. (2005) for A. alba from Spain (50.6\%).

\subsection{Model limitations}

Due to the low amount of data on A. alba biomass, models developed in our study have some limitations. Due to geographic trends clearly visible in biases of allometric trajectories, our models might be suitable to Central European highlands and low mountains. This is connected with climatically driven patterns of biomass allocation (Poorter et al. 2012), shaping relationships between plant biomass and stand features (Schepaschenko et al. 2018). Application of our models is limited by height and diameter ranges - the tallest tree was $32.8 \mathrm{~m}$, while the species studied can reach heights up to $60 \mathrm{~m}$. For that reason, our models would not be suitable in natural, old-growth stands with A. alba. Moreover, we developed our

Table 6 Mean carbon content (\%) in biomass components in each study plot

\begin{tabular}{|c|c|c|c|c|c|c|c|c|c|c|c|c|c|c|c|c|}
\hline \multirow[t]{2}{*}{ Stand age } & \multicolumn{4}{|c|}{ Branches } & \multicolumn{4}{|c|}{ Foliage } & \multicolumn{4}{|c|}{ Stem bark } & \multicolumn{4}{|c|}{ Stem wood } \\
\hline & Min & Mean & SE & Max & Min & Mean & SE & Max & Min & Mean & SE & Max & Min & Mean & SE & Max \\
\hline 8 & 47.1 & 49.3 & 0.3 & 50.2 & 48.3 & 50.4 & 0.4 & 51.6 & 44.9 & 47.0 & 0.2 & 48.5 & 46.8 & 48.2 & 0.2 & 49.3 \\
\hline 13 & 48.8 & 49.3 & 0.2 & 49.9 & 49.9 & 51.5 & 0.3 & 52.5 & 46.2 & 48.7 & 0.2 & 51.1 & 49.3 & 50.2 & 0.1 & 50.7 \\
\hline 22 & 49.0 & 49.6 & 0.2 & 50.3 & 50.7 & 51.6 & 0.2 & 52.6 & 48.2 & 49.3 & 0.1 & 50.7 & 49.4 & 50.1 & 0.1 & 51.6 \\
\hline 40 & 49.6 & 51.1 & 0.3 & 52.6 & 51.5 & 52.2 & 0.1 & 52.7 & 49.2 & 50.8 & 0.2 & 52.6 & 49.9 & 50.5 & 0.1 & 51.5 \\
\hline 41 & 50.8 & 51.1 & 0.1 & 51.7 & 51.7 & 52.4 & 0.1 & 52.9 & 48.2 & 49.8 & 0.2 & 52.4 & 47.5 & 49.7 & 0.1 & 50.5 \\
\hline 57 & 49.9 & 51.2 & 0.3 & 52.2 & 51.7 & 52.1 & 0.1 & 52.6 & 49.6 & 51.1 & 0.2 & 52.8 & 48.6 & 49.4 & 0.1 & 50.1 \\
\hline 68 & 50.5 & 51.2 & 0.2 & 52.0 & 52.0 & 52.6 & 0.2 & 53.1 & 48.3 & 50.5 & 0.2 & 51.9 & 48.9 & 49.6 & 0.1 & 50.3 \\
\hline 78 & 49.3 & 50.3 & 0.2 & 50.8 & 50.8 & 52.4 & 0.3 & 53.4 & 48.2 & 50.5 & 0.2 & 51.7 & 48.6 & 49.4 & 0.1 & 50.7 \\
\hline 82 & 49.9 & 50.8 & 0.2 & 51.4 & 51.0 & 52.0 & 0.2 & 52.9 & 49.4 & 50.5 & 0.1 & 51.6 & 49.2 & 49.6 & 0.1 & 50.2 \\
\hline 93 & 49.9 & 50.9 & 0.3 & 52.0 & 52.3 & 52.7 & 0.2 & 53.8 & 49.7 & 50.8 & 0.1 & 51.9 & 48.9 & 49.7 & 0.1 & 51.8 \\
\hline 107 & 49.8 & 50.9 & 0.3 & 52.1 & 50.8 & 51.8 & 0.2 & 52.2 & 48.6 & 50.1 & 0.2 & 51.4 & 47.8 & 49.8 & 0.1 & 50.6 \\
\hline 115 & 50.1 & 51.5 & 0.3 & 53.1 & 50.2 & 51.4 & 0.2 & 52.3 & 47.5 & 50.4 & 0.2 & 52.9 & 47.7 & 49.3 & 0.1 & 50.1 \\
\hline
\end{tabular}


study in monocultures while in natural conditions A. alba usually grows with an admixture of Picea abies and Fagus sylvatica, and competition effects might also affect biomass allocation and allometric relationships.

\section{Conclusions}

Using a chronosequence of $A$. alba tree stands, our study filled a gap in knowledge about aboveground biomass prediction for this species in Central Europe. We provided a complete set of tree- and stand-level models, as well as values of carbon content, which allow for better characterization of forest carbon pools. We found that the best predictor of biomass at the stand level was stand volume, and the worst were tree stand basal area and stand density. For the stands sampled, our models performed better than other published models, allowing for more reliable biomass estimation. At the stand level, we recommend usage of biomass models instead of BCEFs, as such models are less biased than BCEF models. We also showed the magnitude to which tools more general in scope underestimate or overestimate biomass at the stand level.

Acknowledgements We kindly thank Dr. Lee E. Frelich (The University of Minnesota Center for Forest Ecology, USA) for valuable comments to the manuscript and linguistic support. We are thankful to the two anonymous reviewers for their valuable comments on the earlier draft of the manuscript.

Funding The study was carried out under the research project REMBIOFOR "Remote sensing based assessment of woody biomass and carbon storage in forests", financially supported by The National Centre for Research and Development, Warsaw, Poland, under the BIOSTRATEG program (agreement no. BIOSTRATEG1/267755/4/ NCBR/2015).

Data availability The datasets generated and analyzed during the current study are available in the FigShare repository (Jagodziński et al. 2019) at https://doi.org/10.6084/m9.figshare.7673651.

\section{Compliance with ethical standards}

Conflict of interest The authors declare that they have no conflict of interest.

Disclaimer The funders had no role in the design of the study, in the collection, analyses, and interpretation of data, in the writing of the manuscript or in the decision to publish the results.

Open Access This article is distributed under the terms of the Creative Commons Attribution 4.0 International License (http:// creativecommons.org/licenses/by/4.0/), which permits unrestricted use, distribution, and reproduction in any medium, provided you give appropriate credit to the original author(s) and the source, provide a link to the Creative Commons license, and indicate if changes were made.

\section{References}

Annighöfer P, Ameztegui A, Ammer C, Balandier P, Bartsch N, Bolte A, Coll L, Collet C, Ewald J, Frischbier N, Gebereyesus T, Haase J, Hamm T, Hirschfelder B, Huth F, Kändler G, Kahl A, Kawaletz H, Kuehne C, Lacointe A, Lin N, Löf M, Malagoli P, Marquier A, Müller S, Promberger S, Provendier D, Röhle H, Sathornkich J, Schall P, Scherer-Lorenzen M, Schröder J, Seele C, Weidig J, Wirth C, Wolf H, Wollmerstädt J, Mund M (2016) Speciesspecific and generic biomass equations for seedlings and saplings of European tree species. Eur J For Res 135:313-329. https://doi. org/10.1007/s10342-016-0937-z

Bank Danych o Lasach (2015). http://www.bdl.lasy.gov.pl/. Accessed 31 Jan 2017

Bartoń K (2017) MuMIn: multi-model inference. Available from https:// cran.r-project.org/web/packages/MuMIn/index.html. Accessed 1 Jan 2019

Baskerville GL (1972) Use of logarithmic regression in the estimation of plant biomass. Can J For Res 2:49-53. https://doi.org/10.1139/x72009

Bates D, Maechler M, Bolker B, Walker S (2015). Fitting linear mixedeffects models using lme4. J Stat Soft 67:1-48

Burger H (1951) Holz, Blattmenge und Zuwachs XI. Die Tanne. Mitt Schweiz Anst Forstl Versuchswes 27:247-286

Castedo-Dorado F, Gómez-García E, Diéguez-Aranda U, Barrio-Anta M, Crecente-Campo F (2012) Aboveground stand-level biomass estimation: a comparison of two methods for major forest species in northwest Spain. Ann For Sci 69:735-746. https://doi.org/10.1007/ s13595-012-0191-6

Chave J, Coomes D, Jansen S, Lewis SL, Swenson NG, Zanne AE (2009) Towards a worldwide wood economics spectrum. Ecol Lett 12:351366. https://doi.org/10.1111/j.1461-0248.2009.01285.x

Dobrowolska D, Bončina A, Klumpp R (2017) Ecology and silviculture of silver fir (Abies alba Mill.): a review. J For Res 22:326-335. https://doi.org/10.1080/13416979.2017.1386021

Donnelly L, Jagodziński AM, Grant OM, O'Reilly C (2016) Above- and below-ground biomass partitioning and fine root morphology in juvenile Sitka spruce clones in monoclonal and polyclonal mixtures. For Ecol Manag 373:17-25. https://doi.org/10.1016/j.foreco.2016.04.029

Dyderski MK, Paź S, Frelich LE, Jagodziński AM (2018) How much does climate change threaten European forest tree species distributions? Glob Chang Biol 24:1150-1163. https://doi.org/10.1111/gcb. 13925

Eggleston S, Buedia L, Miwa K, Ngara T, Tanabe K (2006) IPCC guidelines for National Greenhouse Gas Inventories, prepared by the National Greenhouse Gas Inventories Programme. IGES, Tokyo

FAO (2015) Global Forest Resources Assessment. UN Food and Agriculture Organization, Rome

Felipe-Lucia MR, Soliveres S, Penone C, Manning P, van der PF, Boch S, Prati D, Ammer C, Schall P, Gossner MM, Bauhus J, Buscot F, Blaser S, Blüthgen N, de FA, Ehbrecht M, Frank K, Goldmann K, Hänsel F, Jung K, Kahl T, Nauss T, Oelmann Y, Pena R, Polle A, Renner S, Schloter M, Schöning I, Schrumpf M, Schulze E-D, Solly E, Sorkau E, Stempfhuber B, Tschapka M, Weisser WW, Wubet T, Fischer M, Allan E (2018) Multiple forest attributes underpin the supply of multiple ecosystem services. Nat Commun 9:4839. https:// doi.org/10.1038/s41467-018-07082-4

Forrester DI, Tachauer IHH, Annighoefer P, Barbeito I, Pretzsch H, RuizPeinado R, Stark H, Vacchiano G, Zlatanov T, Chakraborty T, Saha S, Sileshi GW (2017) Generalized biomass and leaf area allometric equations for European tree species incorporating stand structure, tree age and climate. For Ecol Manag 396:160-175. https://doi. org/10.1016/j.foreco.2017.04.011

Gasparini P, Nocetti M, Tabacchi G, Tosi V, Reynolds KM (2006) Biomass equations and data for forest stands and shrublands of the 
Eastern Alps (Trentino, Italy). In: USDA General Technical Report PNW-GTR. Edinburg

IPCC (2013) Climate change 2013: the physical science basis. Contribution of Working Group I to the Fifth Assessment Report of the Intergovernmental Panel on Climate Change. Cambridge University Press, Cambridge

Jagodziński AM, Dyderski MK, Gęsikiewicz K, Horodecki P (2018a) Tree- and stand-level biomass estimation in a Larix decidua Mill. chronosequence. Forests 9:587. https://doi.org/10.3390/f9100587

Jagodziński AM, Dyderski MK, Gesikiewicz K, Horodecki P (2019) Abies alba biomass dataset. V 25 April 2019. FigShare. [Dataset]. https://doi.org/10.6084/m9.figshare.7673651

Jagodziński AM, Dyderski MK, Gęsikiewicz K, Horodecki P, Cysewska A, Wierczyńska S, Maciejczyk K (2018b) How do tree stand parameters affect young Scots pine biomass? - allometric equations and biomass conversion and expansion factors. For Ecol Manag 409:74-83. https://doi.org/10.1016/j.foreco.2017.11.001

Jagodziński AM, Oleksyn J (2009a) Ecological consequences of silviculture at variable stand densities. II. Biomass production and allocation, nutrient retention. Sylwan 3:147-157

Jagodziński AM, Oleksyn J (2009b) Ecological consequences of silviculture at variable stand densities. I. Stand growth and development. Sylwan 2:75-85

Jagodziński AM, Zasada M, Bronisz K, Bronisz A, Bijak S (2017) Biomass conversion and expansion factors for a chronosequence of young naturally regenerated silver birch (Betula pendula Roth) stands growing on post-agricultural sites. For Ecol Manag 384:208220. https://doi.org/10.1016/j.foreco.2016.10.051

Köble R, Seufert G (2001) Novel maps for forest tree species in Europe. In: A changing atmosphere, 8th European Symposium on the Physicochemical Behaviour of Atmospheric Pollutants, 17-20 September, Torino

Kuznetsova T, Lukjanova A, Mandre M, Lõhmus K (2011) Aboveground biomass and nutrient accumulation dynamics in young black alder, silver birch and Scots pine plantations on reclaimed oil shale mining areas in Estonia. For Ecol Manag 262:56-64. https://doi.org/10. 1016/j.foreco.2010.09.030

Kuznetsova A, Brockhoff PB, Christensen RHB (2017) lmerTest: tests in linear mixed effects models. J Stat Soft 82. \#13

Lakida P, Nilsson S, Shvidenko A (1996) Estimation of forest phytomass for selected countries of the former European USSR. Biomass Bioenergy 11:371-382. https://doi.org/10.1016/S0961-9534(96) 00030-X

Lamlom SH, Savidge RA (2003) A reassessment of carbon content in wood: variation within and between 41 North American species. Biomass Bioenergy 25:381-388. https://doi.org/10.1016/S09619534(03)00033-3

Ledermann T, Neumann M (2006) Biomass equations from data of old long-term experimental plots. Aust J Forensic Sci 123:47-64

Lehtonen A, Mäkipää R, Heikkinen J, Sievänen R, Liski J (2004) Biomass expansion factors (BEFs) for Scots pine, Norway spruce and birch according to stand age for boreal forests. For Ecol Manag 188:211-224. https://doi.org/10.1016/j.foreco.2003.07.008

Lehtonen A, Palviainen M, Ojanen P, Kalliokoski T, Nöjd P, Kukkola M, Penttilä T, Mäkipää R, Leppälammi-Kujansuu J, Helmisaari H-S (2016) Modelling fine root biomass of boreal tree stands using site and stand variables. For Ecol Manag 359:361-369. https://doi.org/ 10.1016/j.foreco.2015.06.023

Mauri A, de Rigo D, Caudullo G (2016) Abies alba in Europe: distribution, habitat, usage and threats. In: San-Miguel-Ayanz J, de Rigo D, Caudullo G, Houston Durrant T, Mauri A (eds) European atlas of forest tree species. Publication Office of the European Union, Luxembourg, pp 48-49

Mehtatalo L (2008) Forest biometrics with examples in R. Lecture notes for the forest biometrics course. http://cs.uef.fi/ lamehtat/ documents/lecture_notes.pdf. Accessed 4 May 2019
Meier ES, Lischke H, Schmatz DR, Zimmermann NE (2012) Climate, competition and connectivity affect future migration and ranges of European trees. Glob Ecol Biogeogr 21:164-178. https://doi.org/10. $1111 /$ j.1466-8238.2011.00669.x

Mikšys V, Varnagiryte-Kabasinskiene I, Stupak I, Armolaitis K, Kukkola M, Wójcik J (2007) Above-ground biomass functions for Scots pine in Lithuania. Biomass Bioenergy 31:685-692. https://doi.org/10. 1016/j.biombioe. 2007.06 .013

Montero G, Ruiz-Peinado R, Muñoz M (2005) Producción de biomasa y fijación de $\mathrm{CO} 2$ por los bosques españoles. Instituto Nacional de Investigación y Tecnología Agraria y Alimentaria, Madrid

Muukkonen P, Mäkipää R (2006) Biomass equations for European trees: addendum. Silva Fennica 40:475. https://doi.org/10.14214/sf.475

Neumann M, Moreno A, Mues V, Härkönen S, Mura M, Bouriaud O, Lang M, Achten WMJ, Thivolle-Cazat A, Bronisz K, Merganič J, Decuyper M, Alberdi I, Astrup R, Mohren F, Hasenauer H (2016) Comparison of carbon estimation methods for European forests. For Ecol Manag 361:397-420. https://doi.org/10.1016/j.foreco.2015.11. 016

Nord-Larsen T, Nielsen AT (2015) Biomass, stem basic density and expansion factor functions for five exotic conifers grown in Denmark. Scand J For Res 30:135-153. https://doi.org/10.1080/02827581. 2014.986519

Ochał W, Wertz B, Grabczyński S, Orzeł S (2018) Accuracy of estimation silver fir stem mass on the basis of volume to weight conversion factors. Sylwan 162:277-287

Oleksyn J, Reich PB, Chalupka W, Tjoelker MG (1999) Differential above- and below-ground biomass accumulation of European Pinus sylvestris populations in a 12-year-old provenance experiment. Scand J For Res 14:7-17. https://doi.org/10.1080/ 02827589908540804

Pan Y, Birdsey RA, Fang J, Houghton R, Kauppi PE, Kurz WA, Phillips OL, Shvidenko A, Lewis SL, Canadell JG, Ciais P, Jackson RB, Pacala SW, McGuire AD, Piao S, Rautiainen A, Sitch S, Hayes D (2011) A large and persistent carbon sink in the world's forests. Science 333:988-993. https://doi.org/10.1126/science.1201609

Peichl M, Arain MA (2007) Allometry and partitioning of above- and belowground tree biomass in an age-sequence of white pine forests. For Ecol Manag 253:68-80. https://doi.org/10.1016/j.foreco.2007. 07.003

Poorter H, Niklas KJ, Reich PB, Oleksyn J, Poot P, Mommer L (2012) Biomass allocation to leaves, stems and roots: meta-analyses of interspecific variation and environmental control. New Phytol 193: 30-50. https://doi.org/10.1111/j.1469-8137.2011.03952.x

R Core Team (2018) R: a language and environment for statistical computing. R Foundation for Statistical Computing, Vienna

Rademacher P, Khanna PK, Eichhorn J, Guericke M (2009) Tree growth, biomass, and elements in tree components of three beech sites. In: Brumme R, Khanna PK (eds) Functioning and management of European beech ecosystems. Springer, Berlin Heidelberg, pp 105 136

Rieger I, Kowarik I, Cherubini P, Cierjacks A (2017) A novel dendrochronological approach reveals drivers of carbon sequestration in tree species of riparian forests across spatiotemporal scales. Sci Total Environ 574:1261-1275. https://doi.org/10.1016/j.scitotenv. 2016.07.174

Ruiz-Peinado R, del RM, Montero G (2011) New models for estimating the carbon sink capacity of Spanish softwood species. For Syst 20: 176-188

Schepaschenko D, Moltchanova E, Shvidenko A, Blyshchyk V, Dmitriev E, Martynenko O, See L, Kraxner F (2018) Improved estimates of biomass expansion factors for Russian forests. Forests 9:312. https:// doi.org/10.3390/f9060312

Schepashenko D, Shvidenko A, Nilsson S (1998) Phytomass (live biomass) and carbon of Siberian forests. Biomass Bioenergy 14:21-31. https://doi.org/10.1016/S0961-9534(97)10006-X 
56 Page 14 of 14

Annals of Forest Science (2019) 76: 56

Seidl R, Aggestam F, Rammer W, Blennow K, Wolfslehner B (2016) The sensitivity of current and future forest managers to climate-induced changes in ecological processes. Ambio 45:430-441. https://doi. org /10.1007/s13280-015-0737-6

Sohngen B, Than X (2016) Global climate change impacts on forests and markets. Forest Policy Econ 72:18-26. https://doi.org/10.1016/j. forpol.2016.06.011

Spathelf P (2003) Reconstruction of crown length of Norway spruce (Pice abies (L.) Karst.) and Silver fir (Abies alba Mill.) - technique, establishment of sample methods and application in forest growth analysis. Ann For Sci 60:833-842. https://doi.org/10.1051/ forest:2003078

Sprugel DG (1983) Correcting for bias in log-transformed allometric equations. Ecology 64:209-210. https://doi.org/10.2307/1937343

Tabacchi G, Cosmo LD, Gasparini P (2011) Aboveground tree volume and phytomass prediction equations for forest species in Italy. Eur J For Res 130:911-934. https://doi.org/10.1007/s10342-011-0481-9

Teobaldelli M, Somogyi Z, Migliavacca M, Usoltsev VA (2009) Generalized functions of biomass expansion factors for conifers and broadleaved by stand age, growing stock and site index. For Ecol Manas 257:1004-1013. https://doi.org/10.1016/j.foreco.2008. 11.002

Thurm EA, Hernandez L, Baltensweiler A, Ayan S, Rasztovits E, Bielak K, Zlatanov TM, Hladnik D, Baric B, Freudenschuss A, Büchsenmeister R, Folk W (2018) Alternative tree species under climate warming in managed European forests. For Ecol Manas 430:485-497. https://doi.org/10.1016/j.foreco.2018.08.028

Thurner M, Beer C, Santoro M, Carvalhais N, Wutzler T, Schepaschenko D, Shvidenko A, Kompter E, Ahrens B, Levick SR, Schmullius C (2014) Carbon stock and density of northern boreal and temperate forests. Glob Ecol Biogeogr 23:297-310. https://doi.org/10.1111/ neb. 12125

Uni V, Varik M, Aosaar J, Kanal A, Kukumägi M, Lõhmus K (2012) Biomass production and carbon sequestration in a fertile silver birch (Betula pendula Roth) forest chronosequence. For Ecol Manas 267: 117-126. https://doi.org/10.1016/j.foreco.2011.11.033

Wasserstein RL, Lazar NA (2016) The ASA's statement on p-values: context, process, and purpose. Am Stat 70:129-133. https://doi. org /10.1080/00031305.2016.1154108

Wojtan R, Tomusiak R, Zasada M, Dudek A, Michalak K, Wróblewski L, Bijak S, Bronisz K (2011) Współczynniki przeliczeniowe suchej biomasy drzew i ich części da sony pospolitej (Pinus sylvestris L.) w zachodniej Polsce. Sylwan 155:236-243

Zianis D, Muukkonen P, Mäkipää R, Mencuccini M (2005) Biomass and stem volume equations for tree species in Europe. The Finnish Society of Forest Science The Finnish Forest Research Institute, Helsinki

Publisher's note Springer Nature remains neutral with regard to jurisdictional claims in published maps and institutional affiliations.

Springer

INA

SCIENCE \& IMPACT 